\title{
SOCIOECONOMIC STATUS AND PHYSICAL ACTIVITY DURING ELEMENTARY SCHOOL STUDENT RECESS
}

\author{
NIVEL SOCIOECONÔMICO EATIVIDADE FÍSICA DURANTE O RECREIO DE CRIANÇAS DO ENSINO \\ FUNDAMENTAL
}

NIVEL SOCIOECONÓMICO Y ACTIVIDAD FÍSICA DURANTE EL RECREO DE NIÑOS DE LA ENSEÑANZA FUNDAMENTAL

\begin{abstract}
Uriel Zúñiga Galaviz',2 (iD (Physical Education Professional) Rubén Vélez González² (ID) (Physical Education Professional) Jaime Guereca Arvizuo² (iD) (Physical Education Professional) Edson Francisco Estrada Meneses ${ }^{2}$ (iD (Physical Education Professional) Cesar Villalobos Samaniego' (iD) (Physical Education Professional) Iván de Jesús Toledo Domínguez ${ }^{3}$ (D) (Physical Education Professional) Arturo Osorio Gutiérrez ${ }^{3}$ (D) (Physical Education Professional)

1. Universidad Autónoma de Chihuhaua, Chihuahua, Mexico. 2. Universidad Autónoma de Ciudad Juárez, Ciudad Juárez, Mexico.

3. Instituto Tecnológico de Sonora, Obregón, Mexico.
\end{abstract}

Correspondence:

Arturo Osorio Gutiérrez. Rua Sugui, 1012, Cedros I, Cd. Obregón, Sonora, Mexico. 85136. arturo. osorio@itson.edu.mx

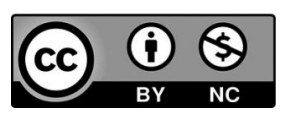

\begin{abstract}
Introduction: The association between socioeconomic status (SES) and the level of physical activity (PA) at school has not been studied at length. Objective: To describe the association between SES and the intensity of physical activity during recess in elementary school children as well as the space dedicated to physical activity. Methods: A total of 212 children ( 110 boys and 102 girls) who were enrolled in the fourth, fifth and sixth grade of elementary school at the time participated in this study. The subjects were divided into 4 levels according to the marginalization index (MI). The geographical location of the schools and the available area were calculated using Google Maps Pro (GMP) software.' Physical activity level was measured using accelerometry. ${ }^{2}$ Comparisons of different levels of PA with respect to marginalization indices and sex were investigated using one-way analysis of variance. The association between health variables and PA was determined through the Pearson correlation coefficient. Results: Results indicated that the level and intensity of PA during recess are associated with socioeconomic status and the social marginalization index, as well as sex, age, and infrastructure. Conclusion: The higher the level of social marginalization, the lower the level of PA and the smaller the space dedicated to PA. Level of Evidence III; Comparative retrospective study.
\end{abstract}

Keywords: Physical activity; Socioeconomic Status; Recreation; Accelerometry.

\section{RESUMO}

Introdução: A associação entre o nível socioeconômico (NSE) e o nível de atividade física (AF) no âmbito escolar tem sido pouco estudada. Objetivo: Descrever a associação entre o NSE e a intensidade da AF durante o recreio em crianças de ensino fundamental e também o espaço dedicado à atividade física. Métodos: Participaram 212 crianças (110 meninose 102 meninas) que, na ocasião do estudo, estavam no quarto, quinto e sexto ano do ensino fundamental. O número de sujeitos foi dividido em quatro níveis de acordo com o índice de marginalização (IM). A localização geográfica das escolas e a área disponivel foram calculadas com o software Google Maps Pro (GMP).' O nivel de atividade física foi medido por acelerometria. As comparações dos diferentes níveis de AF com relação aos indices de marginalização e sexo foram analisadas por variância unidirecional. A associação entre as variáveis de saúde e a AF foi determinada pela correlação de Pearson. Resultados: Os resultados indicaram que o nível e a intensidade de AF durante o recreio estão associados ao nível socioeconômico e ao índice de marginalização social, bem como a sexo, idade e infraestrutura. Conclusões: Quanto maior foi o nível de marginalização social, menor o espaço para praticar e o nível de AF. Nível de Evidência Ill; Estudo retrospectivo comparativo.

Descritores: Atividade física; Nível socioeconômico; Recreação; Acelerometria.

\section{RESUMEN}

Introducción:La asociación entre el nivel socioeconómico (NSE) y el nivel de actividad física (AF) en el ámbito escolar ha sido poco estudiada. Objetivo: Describir la asociación entre el NSEy la intensidad de la AF durante el recreo en niños de enseñanza fundamental y también el espacio dedicado a la actividad física. Métodos: Participaron 212 niños (110 niños y 102 niñas) que, en la ocasión del estudio, estaban en cuarto, quinto y sexto año de la enseñanza fundamental. El número de sujetos fue dividido en cuatro niveles de acuerdo con el índice de marginalización (IM). La localización geográfica de las escuelas yel área disponible fueron calculadas con el software Google Maps Pro (GMP).' El nivel de actividad física fue medido por acelerometría. Las comparaciones de los diferentes niveles de AF con relación a los índices de marginalización y sexo fueron analizadas por variancia unidireccional. La asociación entre las variables de saludy la Af fue determinada por la correlación de Pearson. Resultados: Los resultados indicaron que el nivel y la intensidad de AF durante el recreo están asociados al nivel socioeconómico y al índice de marginalización social, bien como a sexo, edad e infraestructura. Conclusiones: Cuanto mayor sea el nivel de marginalización social, menor será el espacio para practicar y el nivel de AF. Nivel de Evidencia III; Estudio retrospectivo comparativo.

Descriptores: Actividad física; Nivel socioeconómico; Recreación; Acelerometría. 


\section{INTRODUCTION}

Data obtained by the Mexican National Council for the Evaluation of Social Development Policy' mention that almost 95 of the 122 million people living in Mexico experience some form of poverty or have low socioeconomic status (SES). ' Another way of cataloguing SES is through the National Population Council (CONAPO), ${ }^{2}$ which assigns a marginalization index (MI) based on health services, water, drainage, wall coating materials, assets and income, besides different variables included in other studies. ${ }^{3}$ In recent years, the emphasis has been placed on the study of SES and its link to health indicators, such as the level of physical activity. ${ }^{4}$

It is known that the lower the SES, the greater the tendency to suffer from low levels of physical activity. ${ }^{4,5}$ More recent data published by Lampinen et al. (2017) confirms that children whose parents' income is higher engage in physical activity for more than twice as long as their peers. Although a sedentary lifestyle is not specifically associated with people with low SES, it is important to consider the extent to which this factor influences the child population. In Mexico, sedentary lifestyles are found among almost $60 \%$ of children aged 10 to 14 years. ${ }^{7}$ Thus, it is claimed that a large number of children in Mexico do not meet the minimum PA requirements of international organizations.

On the other hand, it has been pointed out that most children will grow to adulthood occupying the same SES and being overweight due to lack of physical activity. ${ }^{8}$ It is therefore widely known that childhood socioeconomic status has proved to be a powerful predictor of health in adulthood. ${ }^{9}$ Therefore, problems related to SES that arise at an early age are likely to be reflected in adulthood.

It is known that little or no physical activity undertaken as a recreational activity during leisure time is one of the main cause of overweight and obesity..$^{10}$ Childhood obesity and overweight are a public health problem in Mexico, where a prevalence of overweight and obesity was reported in 34.4\% of children between 5 and 11 years of age. ${ }^{7}$ Mexico currently ranks high in terms of overweight and obesity. ${ }^{11}$ However, it is not the only country with this issue; childhood obesity is an international public health crisis and its prevalence has increased over just a few years.

Other studies have shown that an effective method to promote active lifestyles, reduce obesity and contribute to the acquisition of a healthy state is precisely physical activity. ${ }^{12}$ For this reason, an increase in the amount of PA performed at school could promote active lifestyles. During schooltime there are at least two prime opportunities for students to undertake PA, one of which is in physical education (PE) classes and the other during recess. At the basic level of public institutions, it is common to teach $1 \mathrm{~h} /$ week of PE and 30 minutes of daily recreation; conversely, in private schools, students receive $2 \mathrm{~h} /$ week of physical education lessons and have 2 recesses per day, but this population represents only $8 \%$ of the school population in the state of Chihuahua, Mexico.

There is evidence that the use of adequate leisure time at school has positive effects on the child, but some of the conclusions are limited to mentioning that boys undertake more PA than girls during recess. ${ }^{13}$ It has been demonstrated that the school infrastructure and PA performed at school maintain a positive and significant relationship, with leisure areas in playgrounds being associated with higher levels of physical activity in children. ${ }^{14-16}$ Dessing et al. ${ }^{17}$ established that PA performed by children in the recreation area during recess was greater in terms of time and intensity than the average PA performed by children outside school.

During the transition from childhood to adolescence, there may be a decrease in PA. ${ }^{18}$ It is necessary to explain in further detail the extent to which physical activity is associated with socioeconomic parameters and school infrastructure. A better understanding of the social and biological factors that influence PA would effectively serve as a basis for the design and implementation of PA models in schools.
The aim of this particular study was to describe the association between the marginalization index, the intensity and area devoted to physical activity during recess, and the sex or gender of children enrolled in the fourth to sixth grades of elementary education in public schools in Ciudad Juárez, Chihuahua, in addition to the influence of age and $\mathrm{BMI}$ on the variables described above.

\section{MATERIALS AND METHODS}

\section{Study population}

A total of 264 students from 11 elementary schools in Ciudad Juárez, Chihuahua, were selected. This was followed by the systematic selection of 24 students, with 8 from each grade $\left(4^{\text {th }}, 5^{\text {th }}\right.$ and $6^{\text {th }}$ - the first 8 students on the official list of each school according to the order of the official list and the material available). Eight accelerometers (one for each child) were evaluated on only one occasion during the month of May. At the end of the study, 110 boys and 102 girls covered all the variables to be assessed. They were divided into 4 SES according to the marginalization index (MI) of the area of the primary school in which they were enrolled, totaling 77 students categorized as MI1, 48 as MI2, 40 as MI3 and 47 as MI4. The principal, group teacher and parents signed a letter of participation and informed consent in accordance with the Declaration of Helsinki guidelines. ${ }^{19}$ Moreover, the institutional review board of UACJ reviewed and accepted the research protocol (CIBE-2016-1-49).

\section{Instruments}

Socioeconomic status. The first step consisted of finding the geographical location of each school to which each student belonged using Google maps Pro version software. ${ }^{20}$ The map of the metropolitan area of Ciudad Juárez, Chihuahua, was also obtained with the marginalization index according to each geographical area disclosed by the national population council. ${ }^{2}$ Overlapping of the two images was used between the abovementioned maps. Once the participating schools and the Ml of the area to which the school belongs were located, a value from 1 to 5 was assigned as follows: MI1 corresponds to a very low marginalization index, i.e., the school belongs to an area with a high SES while MI5 corresponds to greater poverty. The participating schools by MI were: 3 from MI1, 3 from MI2, 2 from MI3 and 3 from MI4. None of the schools were categorized as MI5.

Anthropometric variables. Anthropometric measurements, height and weight were obtained one hour before recess in accordance with the International Standards for Anthropometric Assessment manual published by the International Society for the Advancement of Kinanthropometry (ISAK), according to Norton et al. ${ }^{21}$ Body weight was measured in kilograms using an electronic scale (model OMRON HBF-514C) with an error of $0.1 \mathrm{~kg}$. Height was measured using a stadiometer attached to the wall with marks in centimeters. BMI was obtained using the formula $\mathrm{BMI}=\mathrm{kg} / \mathrm{m}^{2}$ adjusted for age and sex.22

Physical activity. The wGT3X-BT ${ }^{23}$ accelerometers were configured using the full version of Activlife v6.11.8 software, Pensacola, Florida, USA. They were connected to the USB port of the computer and the first and last names of each individual participating child was assigned to each one. The total recording time was 30 minutes during recess, after which the intensity of physical activity was classified as follows: values below 1.6 METS were classified as sedentary, values from 1.6 to 3 METS as light activity, values from 3 to 6 METS as moderate, and values from 6 to 9 METS as vigorous. ${ }^{21}$ Playing surface. The first step consisted of measuring the total area of the school and the rest of the built-up surface, along with the classrooms, space for plants and areas that are off-limits to the children, resulting in the total recreation area or area to which the children had access and where they engaged in recess-time activities, all using the software (GMP) with the polygon and rule tool. ${ }^{21}$ The children's total playing area 
(in square meters) was divided by the total number of students who leave the classroom for recess at the same time to obtain the available surface area per student during recess.

\section{Statistical Analysis}

Descriptive statistics were used to determine means and standard deviations of all measured variables. The one-way analysis of variance was applied to establish differences between PA levels in relation to marginalization levels and gender, while the relationship between BMI and PA was determined using Pearson's correlation coefficient. A regression test was applied to determine independence between the variables analyzed between the intensity of PA measured in METS, the marginalization index, the recreation space and age. The SPSS v21.0 statistical package for Windows, Armonk, NY, EU, was used for the calculations. Significance $\leq 0.05$ was considered in all the assessments.

\section{RESULTS}

The percentages of the participants by MI were found to be between 20 and $34 \%$ and were homogeneous (Table 1).

Table 2 shows the results of the population divided by MI. No differences in height, weight, age and BMI were found between students from schools in different marginalization index areas.

The METS values reported were higher in the MI1 schools than in the other groups ( $p<0.05$ ). Regarding the percentage of sedentary lifestyles, the group with the highest values was MI3 $(p<0.05)$. The recreation area was larger in the school with MI-1 and MI-4, followed by MI-3 and MI-2, respectively (Table 3).

Table 4 shows the intensity of PA during school recess between boys and girls. Boys performed more moderate PA, while girls engaged in lighter activities $(p<0.01)$.

Table 5 shows the matrix of correlations between gender, age and METS with values of the recess environment, $\mathrm{MI}$ and $\mathrm{BMI}$. The variable gender/sex was negatively correlated with BMI adjusted for age ( $p<0.05)$, while the space available to students was negatively correlated with age $(p<0.01)$. METS during recess was positively correlated with the space available for PA during recess, and negatively correlated with the marginalization index.

Table 1. Population assessed by socioeconomic status and level of education.

\begin{tabular}{|c|c|c|c|c|c|c|c|}
\hline & MI1 & MI2 & \multicolumn{2}{|c|}{ MI3 } & \multicolumn{3}{|c|}{ MI4 } \\
\hline SG & 456 & 456 & 4 & 56 & & 5 & 6 \\
\hline $\begin{array}{c}\text { Boys and girls by MI } \\
\text { and SG }(n=212)\end{array}$ & 163130 & 16248 & 16 & 816 & 15 & 16 & 16 \\
\hline $\begin{array}{l}\text { Boys and girls by } \\
\text { Ml and SG (\%) }\end{array}$ & 488 & $9 \quad 178$ & 9 & 49 & 8 & 8 & 8 \\
\hline $\begin{array}{l}\text { Boys and girls by } \\
\text { MI }(n=212)\end{array}$ & 77 & 48 & & 40 & & 47 & \\
\hline Boys and girls by MI (\%) & 20 & 34 & & 21 & & 25 & \\
\hline
\end{tabular}

Table 2. General data of the population by marginalization index.

\begin{tabular}{c|c|c|c|c}
\hline & MI1 $(\mathbf{n}=\mathbf{7 7})$ & MI2 $(\mathbf{n = 4 8})$ & MI3 $(\mathbf{n}=\mathbf{4 0})$ & MI4 $(\mathbf{n = 4 7 )}$ \\
\hline Height, $\mathrm{cm}$ & $143.83 \pm 9.1$ & $141.84 \pm 6.25$ & $141.94 \pm 7.68$ & $143.51 \pm 7.11$ \\
\hline Weight, $\mathrm{kg}$ & $41.83 \pm 12.04$ & $39.65 \pm 10.81$ & $40.20 \pm 9.93$ & $39.16 \pm 8.95$ \\
\hline Age, years & $10.86 \pm 1.06$ & $10.72 \pm 0.85$ & $10.75 \pm 1.05$ & $10.92 \pm 1.07$ \\
\hline BMI, $\mathrm{kg} / \mathrm{m}^{2}$ & $19.93 \pm 4.25$ & $19.54 \pm 4.34$ & $19.78 \pm 3.75$ & $18.90 \pm 3.52$ \\
\hline Note. Values are presented as means \pm SD. MI = marginalization index, BMI = body mass index.
\end{tabular}

\section{DISCUSSION}

The association between the intensity of physical activity performed during recess, the available recreation area and socioeconomic status in public schools in Mexico was analyzed. Children frequenting less marginalized schools generate more METS during recess. The size of the available play areas correlates positively with the level of physical activity performed during recess. Boys engage in more moderate PA, while girls perform light PA more often.

Students belonging to schools located in geographical regions that coincide with a better MI, i.e., those in Ml1, achieved the highest quantity of METS through PA performed during recess. MI1 schools probably have teaching materials in their schools, such as balls, ropes or other additional resources, or allow the students themselves to carry and use these materials, which, in turn, can affect PA performed during this timeframe. According to Baquet et al., ${ }^{4}$ sports courts, grassed areas, trees, games, cement and shady areas tend to favor PA, but these aspects were not evaluated in this particular study. However, part of the infrastructure was assessed in terms of total playing areas to which students have access during recess. Escalante et al. ${ }^{14}$ \& Nichol et al. ${ }^{24}$ demonstrate that leisure areas are important indicators of PA inside the school, for example, areas under $28 \mathrm{~m}^{2}$ per student available to perform PA inside the school are considered small areas. In this study, marginalization indices 2 and 3 obtained this classification and schools belonging to MI1 and MI4 obtained 43.66 and 34.24, respectively (values above $28 \mathrm{~m}^{2}$ ) and were classified as large playing areas. However, the available space in square meters per student obtained in this study is much smaller, according to the classification of Harten, Olds, \& Dollmann ${ }^{25}$, who categorize areas under $80 \mathrm{~m}^{2}$ per capita as small and areas over $80 \mathrm{~m}^{2}$ as large.

The playing surface results obtained in our study are similar to those found in the analysis carried out by Tonge et al. (2016) ${ }^{26}$ on factors related to physical activity levels in children. Regarding environmental variables, the authors concluded that the availability of outdoor spaces is a factor closely related to the level of physical activity in children. In addition, a positive association was found between the recreation area and the level of physical activity. However, the relationship between the level of physical activity and the surface available for physical activity is still an element that requires further study, due to the different factors involved in this topic

Table 4. Intensity of physical activity of the population assessed during recess by gender

\begin{tabular}{c|c|c}
\hline & Boys $(\mathbf{n}=110)$ & Girls $(\mathbf{n}=\mathbf{1 0 2})$ \\
\hline METS & $4.50 \pm 0.91$ & $4.40 \pm 0.90$ \\
\hline Sed, \% & $2.84 \pm 4.86$ & $2.51 \pm 3.84$ \\
\hline Lig, \% & $25.12 \pm 16.71$ & $38.91 \pm 16.07^{* *}$ \\
\hline Mod, \% & $72.03 \pm 18.23$ & $58.57 \pm 17.26^{* *}$ \\
\hline
\end{tabular}

Note. Percentages correspond to the time devoted to each physical activity intensity, values are presented as means \pm SD. Sed $=$ sedentary lifestyle, Lig $=$ Light, Mod $=$ moderate, ${ }^{* *} p<0.01$

Table 5. Matrix of correlation between general data and intensity of PA of the population and parameters of the school.

\begin{tabular}{c|c|c|c}
\hline & Recreation space & MI & BMI for age \\
\hline Gender 1,2 & 0.09 & -0.02 & $-0.14^{*}$ \\
\hline Age & $-0.22^{* *}$ & 0.02 & -0.06 \\
\hline METS during recess & $0.41^{* *}$ & $-0.42^{* *}$ & 0.03 \\
\hline
\end{tabular}

Table 3. Intensity of physical education of the population during recess by marginalization index.

\begin{tabular}{|c|c|c|c|c|}
\hline & MI1 $(n=77)$ & $M I 2(n=48)$ & MI3 $(n=40)$ & MI4 (n=47) \\
\hline METS & $4.99 \pm 1.00 b^{* * *}$ & $4.38 \pm 0.82 c^{*}$ & $3.81 \pm 0.37 a^{* * *}$ & $4.15 \pm 0.60 a^{* * *}$ \\
\hline Sed, $\%$ & $2.01 \pm 3.4 c^{* *}$ & $2.70 \pm 5.12 c^{*}$ & $5.06 \pm 5.77 d^{* *}$ & $1.73 \pm 2.7$ \\
\hline Light, \% & $35.55 \pm 19.06$ & $28.38 \pm 21.24$ & $31.53 \pm 13.65$ & $29.18 \pm 13.61$ \\
\hline Mod, \% & $62.43 \pm 19.70$ & $68.90 \pm 23.34$ & $63.39 \pm 14.71$ & $69.08 \pm 14.97$ \\
\hline Recreation surface per child m2 & $43.01 \pm 46.90 b^{* * *}$ & $8.33 \pm 0.86 c^{*}$ & $25.46 \pm 10.93 a^{*}$ & $34.24 \pm 23.06 b^{* * *}$ \\
\hline
\end{tabular}


(available equipment, type of climate, scheduled activities, etc.). For example, the mixed study conducted by Pawlowski et al. (2016)27 determined that the availability of the type of activities that can be performed in recreation areas creates a predisposition to the gender involved in such activities. If the recreation area is a soccer field, boys are more likely to show more interest than girls and, therefore, it is this group that has the highest level of physical activity. Reimers et al. (2017) $)^{28}$ mentions that there is a relationship between surface area and levels of physical activity in children, but we cannot forget to respond to the needs of physical activity, providing different types of activities to include the participation of all genders.

Regarding sedentary lifestyle, MI3 was the group with the highest percentage. Just over $5 \%$ of the students assessed in the study were included in this category, yet the values are well below the $38 \%$ of sedentary lifestyle reported by Baquet et al. ${ }^{4}$ for very similar populations. Thus we deduce that elementary school students engage in various physical activities during recess.

METS during recess was negatively correlated with the marginalization index. These results are widely consistent with the literature, as several authors including Singh, Kogan, Siahpush and van Dyck ${ }^{29}$ determined this negative relationship between PA and marginalization.

As regards the intensity of PA that was performed by boys and girls during recess, it could not be particularly demanding. However, boys engaged in moderate PA more frequently than girls, while girls engaged in light PA more often. These differences in gender and intensity have also been reported by various authors., 4,13,17,19,30

According to the results obtained in this article and pursuant to the interpretation in the literature, the physical space conditions our way of expressing ourselves, adapts our vision and determines reference points. Children may feel indifferent towards developing healthy and harmonious bonds with the environment if the school fails to provide spaces with green areas, which are pleasing to the senses, favorable, and that meet, at the very least, the basic needs for physical activities. This shortage of adequate facilities in schools can be an indication of the lack of quality related to physical space and of facilities for the development of Physical Education lessons, discouraging the children from engaging in regular physical activities during recess. School-based physical activities involve goals that are directed either at motor development, improvement of quality of life and health, or body culture assimilation. Thus, we must consider the problem of working conditions of teaching staff so that physical activity can consolidate its importance and continuity within the area of primary education once the deficiencies of physical space and quality facilities have been resolved.

\section{CONCLUSIONS}

PA and intensity during recess are associated with variables of different types, both socioeconomic and relating to the social marginalization index, gender, age, physical indicators and infrastructure. The greater the social marginalization, and the older and smaller the playing area, the lower the intensity of PA. Boys and girls perform physical activity of different intensity during recess.

\section{ACKNOWLEDGMENTS}

We wish to express our gratitude to those who participated voluntarily, to the students, the parents, principals and teachers who generously collaborated in this work. This study was carried out with the financial support of PRODEP and of ICB-UACJ and FCCF, which provided the necessary resources to carry out this work.

All authors declare no potential conflict of interest related to this article

AUTHORS' CONTRIBUTIONS: Each author made significant individual contributions to this manuscript. UZG: Conception and design of the work, data analysis and interpretation, writing and final approval of the version of the article to be published. RVG: Data analysis and writing. JGA, EFEM and AOG: Statistical analysis and writing. IJTD and CVS: data interpretation and results analysis. AOG: Approval of the final version of the article, intellectual content critique.

\section{REFERENCES}

1. CONEVAL. Pobreza em Mexico. 2016 [Acesso em 13 set. 2017]. Disponível em: http://www.coneval. org.mx/Medicion/MP/Paginas/Pobreza_2016.aspx.

2. 2CONAPO. Índice de marginación por localidad. México, DF: Consejo Nacional De Población; 2012 [Acesso em 28 de maio 2014:]. Disponível em: http://www.conapo.gob.mx/es/CONAPO/ Indice_de_Marginacion_por_Localidad_2010

3. Cameron AJ, Ball K, Pearson N, Lioret S, Crawford DA, Cambell K, et al. Socioeconomic variation in diet and activity-related behaviours of Australian children and adolescents aged $2-16$ years. Pediatr Obes. 2012;7(4):329-42.

4. Baquet G, Ridgers ND, Blaes A, Aucouturier J, Van Praagh E, Bertholn S. Objectively assessed recess physical activity in girls and boys from high and low socioeconomic backgrounds. BMC Public Health. 2014;14:192.

5. Lioret S, Maire B, Volatier JL, Charles MA. Child overweight in France and its relationship with physical activity, sedentary behaviour and socioeconomic status. Eur J Clin Nutr. 2007;61(4):509-16.

6. Lampinen EK, Eloranta AM, Haapala EA, Lindi V, Väistö J, Lintu N, et al. Physical activity, sedentary behaviour, and socioeconomic status among Finnish girls and boys aged 6-8 years. Eur J Sport Sci. 2017;17(4):462-72.

7. ENSANUT. Encuesta Nacional de Salud y Nutricion 2012. Resultados nacionales. México: Instituto Nacional de Salud Publica; 2012.

8. Dollman J, Ridley A, Magarey A, Martin M, Hemphill E. Dietrary intake, physical activity and tv viewing as mediators of the association of socioeconic status with body composition : a cross-sectional analysis of Australian youth. Int J Obes (Lond). 2007;31(1):45-52.

9. Cohen S, Janicki-Deverts D, Chen E, Matthews KA. Childhood socioeconomic status and adult health Ann N Y Acad Sci. 2010;1 186:37-55.

10. Story M, Nanney MS, Schwartz MB. Schools and Obesity Prevention: Creating School Environments and Policies to Promote Healthy Eating and Physical Activity. Milbank Q. 2009;87(1):71-100.

11. OECD. Obesity Update. 2014 [Acesso em 10 de outubro 2015]. Disponpivel em: http://www.oecd.org/ health/Obesity-Update-2014.pdf

12. Hayes LB, Van Camp CM. Increasing physical activity of children during school recess. J Appl Behav Anal. 2015;48(3):690-5

13. Patnode CD, Lytle LA, Erickson DJ, Sirard JR, Barr-Anderson D, Story M. The relative influence of demographic, individual, social, and environmental factors on physical activity among boys and girls. Int J Behav Nutr Phys Act. 2010;7:79.

14. Escalante Y, Backx K, Saavedra JM, García- Hermoso A, Domínguez AM. Play area and physical activity in reces in primary schools. Kinesiology. 2012;42:123-9.
15. Ridgers ND, Fairclought S. Assessing free-living physical activity using accelerometry: Practical issues for researchers and practitioners. Eur J Sport Sci. 2011;11(3):205-13.

16. Taylor RW, Farmer VL, Cameron SL, Jones KM, Williams SM, Mann JL. School playgrounds and physical activity policies as predictors of school and home time activity. Int J Behav Nutr Phys Act. 2011;8:38.

17. Dessing D, Pierik FH, Sterkenburg RP, Dommelen PV, Maas J, Vries SI. Schoolyard physical activity of 6-11 year old children assessed by GPS and accelerometry. Int J Behav Nutr Phys Act. 2013;10:97.

18. Ridgers ND, Timperio A, Crawford D, Salmon J. Five-year changes in school recess and lunchtime and the contribution to children's daily physical activity. Br J Sports Med. 2012;46(10):741-6.

19. Ridgers ND, Fairclough SJ, Stratton G. Variables associated with children's physical activity levels during recess: the A-CLASS project. Int J Behav Nutr Phys Act. 2010;7:74.

20. Datos mapa, GOOGLE, INEGI. (15 de 02 de O2015). Google Earth Pro. Mountain View, CA, EE.UU.

21. Norton K, Norton L, Sadgrove D. Position statement on physical activity and exercise intensity terminology. J Sci Med Sport. 2010;13(5):496-502.

22. OMS. World Health Organization [ acessado em 15 fev. 2007]. Disponivel em: http://www.who.int/ growthref/publications/en/

23. ActiGraph L. (19 de 11 de 2015). Actilife 6.11.8. Pensacola, Florida, EUA.

24. Nichol ME, Pickett W, Janssen I. Associations Between School Recreational Environments and Physical Activity. J Sch Health. 2009;79(6):247-54.

25. Harten N, Olds T, Dollman J. The effects of gender, motor skills and play area on the free play activities of 8-11 year old school children. Health Place. 2008;14(3):386-93.

26. Tonge KL, Jones RA, Okley AD. Correlates of children's objectively measured physical activity and sedentary behavior in early childhood education and care services: A systematic review. Prev Med. 2016;89:129-39.

27. Pawlowski CS, Andersen HB, Trolesen J, Schipperijn J. Children's Physical Activity Behavior during School Recess: A Pilot Study Using GPS, Accelerometer, Participant Observation, and Go-Along Interview. PLos One. 2016;11(2):e0148786.

28. Reimers AK, Knapp G. Playground usage and physical activity levels of children based on playground spatial features. J Public Health. 2017;25:661-9.

29. Singh GK, Kogan MD, Siahpush M, van Dyck PC. Independent and Joint Effects of Socioeconomic, Behavioral, and Neighborhood Characteristics on Physical Inactivity and Activity Levels Among US Children and Adolescents. J Community Health. 2008;33(4):206-16.

30. Dyment JE, Anne C, Bell AC, Lucasa AJ. The relationship between school ground design and intensity of physical activity. Child Geogr. 2009;7(3):261-76. 